\title{
Performance of Cuk-KY Converter Fed Multilevel Inverter for Hybrid Sources
}

\author{
V.Vasudevan*, K.Balaji \\ Department of Electrical and Electronics Engineering \\ St. Peters Institute of Higher Education and Research, Avadi, Chennai 600054, India
}

\begin{tabular}{l} 
Article Info \\
Article history: \\
Received Nov 18, 2017 \\
Revised Jan 23, 2018 \\
Accepted Feb 14, 2018 \\
\hline Keywords: \\
Fuel cell \\
Maximum Power Point \\
Tracking (MPPT) \\
Multi Level Inverter (MLI) \\
Photo Voltaic (PV) \\
Pulse Width Modulation (PWM
\end{tabular}

Corresponding Author:

V.Vasudevan,

Department of Electrical and Electronics Engineering,

St. Peters Institute of Higher Education and Research,

Avadi, Chennai 600054, India

Email: vasudevan1phd@gmail.com

\begin{abstract}
Distributed energy source based electricity generation is an essential factor for the economic growth and development of a country. The photovoltaic, fuel cell and battery based power generation offer a high voltage gain. The DC-DC CUK converter based on both buck and boost mode of operation is proposed for high gain dc link voltage. The hybrid CUK -KY Converter based multilevel inverter is designed and implemented. Here, the main advantages of hybrid boost mode operation of Cuk converter, step up configuration is used which will result in improve conversion voltage ratio and better damping of oscillations. The DC-DC converter voltage has regulated by the maximum power point tracking and PI control based method is used. The cascaded multilevel inverter in hybrid renewable energy production integrating with switched capacitor method is designed. The proposed converter is designed and implemented in MATLAB/SIMULINK environment.
\end{abstract}

Copyright () 2018 Institute of Advanced Engineering and Science. All rights reserved.

\section{INTRODUCTION}

The renewable energy based power generation generates less voltage it will be increased by the dcdc converter. The multilevel inverter has used in industrial application for high power conversion such as reactive power compensator, FACTS devices, traction drives. In photovoltaic power generation the boost DC-DC converters are widely used. In semiconductor devices the soft switching characteristics is attained and also reduce the switching losses by the Cuk converter based on discontinuous capacitor voltage mode. The Cuk converter switches are on and off by zero voltage and current switching [1]. The step up converter is used in the switched mode power supply device. The Cuk converter based power generation has not use the inductor filter at the output side and transferring the quality power by using the control methods. The Cuk converter having a continuous current at both input and output sides and used for performance analysis. Interleaved Cuk converter is used to reduce the input current ripple and also to improve transient performances. The advantages of Cuk converter having better efficiency attributable to cancellation of source current ripple, reduction of ripple content in both output voltage and current, and improvement of transient performance [2-4]. The step up converter generate large output voltage ripples and slow transient response due to the pulsating output capacitor current and the right-half plane zero in transfer function from duty ratio to output voltage. The KY converter has less output voltage ripples and fast transient response compared with the boost converter. The integrated KY converter has designed with power components including energy transferring capacitor, inductor, and filter capacitor are evaluated [5]. The KY converter has 
integration of synchronous rectified boost converter and coupled inductor. This converter has analyzed the relationship of output voltage and load current.

The KY converter has high voltage gain by the integration of two converters such as boost and inductor coupled. The leakage inductance of the coupled inductor is used to attain the zero voltage switching (ZVS) and the current stress on the charge pump capacitors and the decreasing rate of the diode current can be limited due to the use of the coupled inductor and output current is non-pulsating [6]. The KY converter based multilevel modular inverter has decrease the voltage and current stress of switching device and increase the efficiency of the converter based system. The output voltage of the Cuk based multilevel inverter has increases the high gain by the turn's ratio and duty cycle. The output of the KY converter has both buck as well as boost converter [7]. The $\mathrm{H}$ bridge inverter has used to reduce the power switches, losses, voltage stress and converter cost. The multilevel inverter has reduces the harmonics and improve the performance of the converter system. The photovoltaic energy based inverter system has effective and efficient power electronic device interface with source. The inverter has operated in both symmetrical and asymmetrical mode [9-11].

\section{SYSTEM DESCRIPTION}

The multilevel inverter has to decrease the voltage stress and harmonic distortion. The multilevel inverter has used more number of switches as compared to conventional two level inverters [8]. The multilevel inverter based hybrid converter such as Cuk and KY. The controller of KY Converter utilizes the maximum power point tracking control method for generating high power from the photovoltaic source [12]. The fuel cell based Cuk converter produce the voltage by the PI control methodology. The block diagram of proposed system is shown in Figure 1.

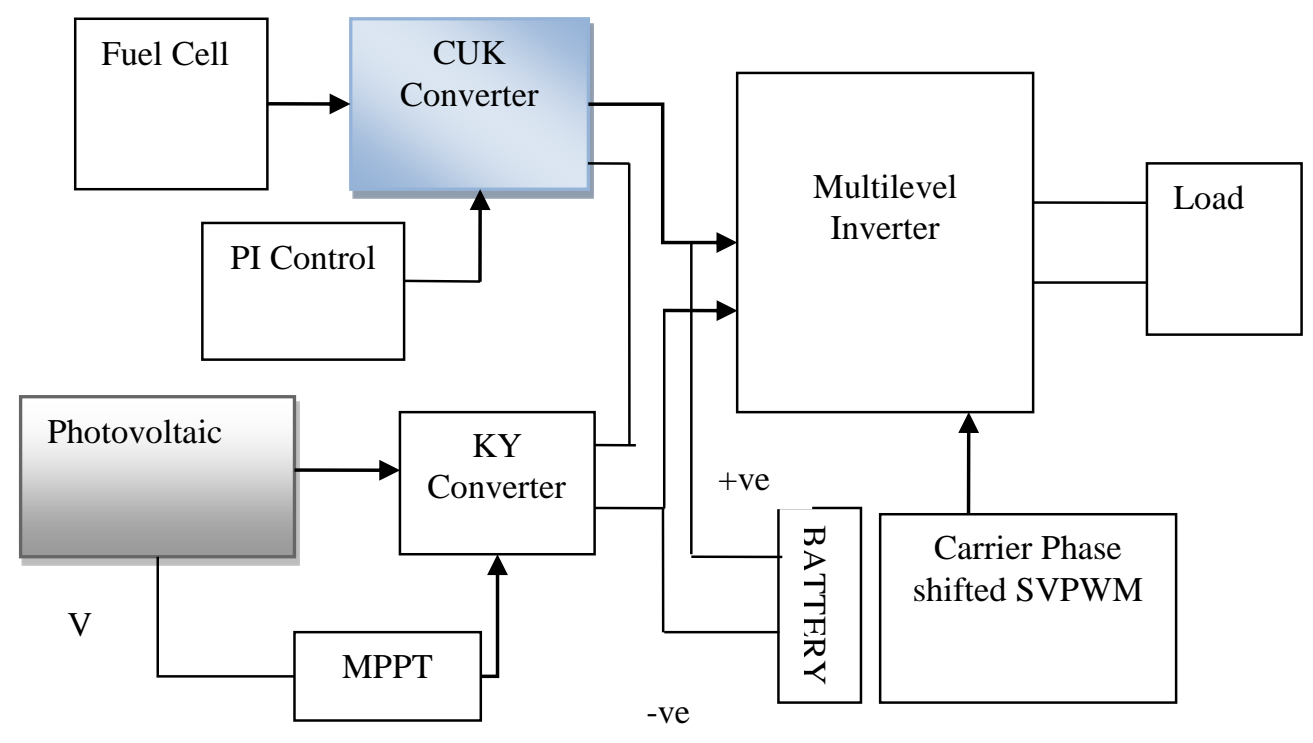

Figure 1. Block diagram of Proposed Method

The renewable energy such as solar and fuel cell generate the dc voltage having less magnitude. The voltage is improved by the Cuk and KY converter is cascaded and the de link output is fed into the multilevel inverter will generate comparatively less total harmonic distortion and improved the efficiency of the inverter fed renewable energy system [13-14]. The dc link voltage is compared with reference voltage and is fed into the PI control based pulse width modulation will regulate the output of the Cuk based fuel cell. The KY converter utilizes the maximum power point tracking for improving the voltage gain as well as regulates the voltage. 


\section{DYNAMIC MODELING OF PROPOSED METHOD}

\subsection{Solar Power Generation}

The solar based renewable energy produces the power from radiation. The semiconductor material used to convert the sunlight radiation into electricity. The photovoltaic system has an important for distributed power generation. PV system consists of number of solar cells these are connected in series for generating electrical power with high potential. The photons of light fall on the semiconductor material and the electrons flow in the material [17]. The proposed solar power generation has nonlinear power can change with the environmental condition, less maintenance and cost effective. The voltage produced from the PV cell depends on the semiconductor used and also varying temperature, insolation etc. The PN junction absorbs the radiation and forms the electron hole pair [15]. Thus the light energy is converted to electrical energy. The single diode PV module is shown in Figure 2.

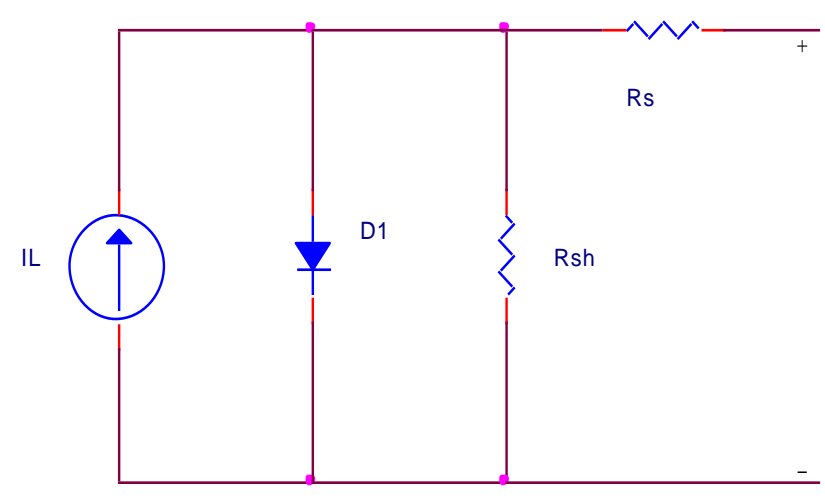

Figure 2. Photovoltaic Cell

In PV the current source indicate the light generate the current.

$$
I_{\text {diode }}=I_{o}\left(-1+e^{\frac{q V}{K T}}\right)
$$

Where Io=saturation current,

$\mathrm{V}=$ applied voltage,

$\mathrm{K}=$ Boltzmann constant,

$\mathrm{T}=$ Temperature

$\mathrm{Q}=$ electron charge

\subsection{Fuel Cell}

The fuel cell based renewable energy generation has several types. The proposed proton exchange membrane based fuel cell generates a .071 voltage. The fuel cells are electrically connected in series forming a stack which provides a large power at high voltage and current levels. The PEM based fuel has three components such as cathode, anode and solid polymer electrolyte membrane. The advantages of fuel cell have low temperature, high power density, fast response and zero emission. The chemical reactions occurring at the anode and cathode electrode of a PEM fuel cell is given as,

$\begin{array}{ll}\text { Anode Reaction: } & 2 \mathrm{H}_{2} \rightarrow 4 \mathrm{H}^{+}+4 e^{-} \\ \text {CathodeReaction: } & \mathrm{O}_{2}+4 \mathrm{H}^{+}+e^{-} \rightarrow 2 \mathrm{H}_{2} \mathrm{O} \\ \text { TotalCellReaction: } & 2 \mathrm{H}_{2}+\mathrm{O}_{2} \rightarrow 2 \mathrm{H}_{2} \mathrm{O}+\text { electricity }+ \text { heat }\end{array}$ 


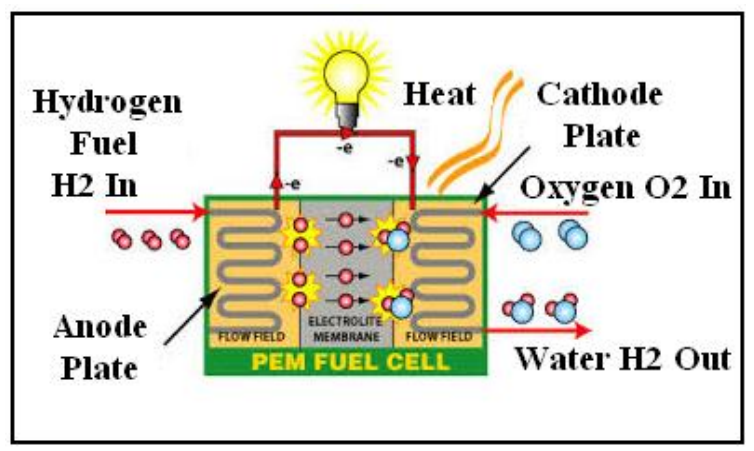

Figure 3. Schematic Diagram of PEMFC

The schematic diagram of proton exchange membrane based on fuel cell Figure 4 shows the equivalent circuit diagram of fuel cell. The voltage of the fuel cell is given below in equation.

$$
V_{\text {cell }}=E_{\text {thermo }}-V_{\text {act }}-V_{\text {ohmic }}-V_{\text {conc }}
$$

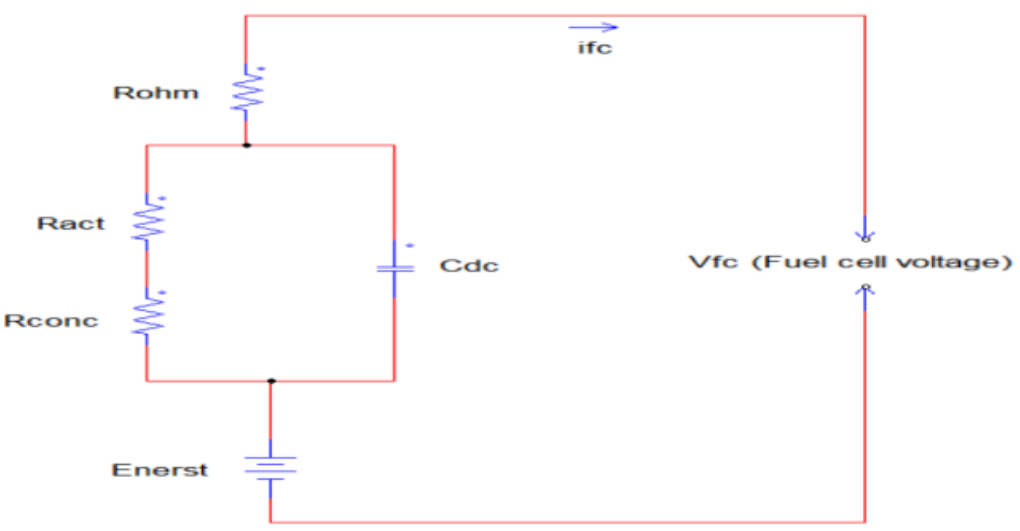

Figure 4. Equivalent Circuit of Fuel cell

\subsection{Cuk Converter}

The Cuk converter is similar as buck boost converter but the output of the converter is negative in magnitude. The Cuk converter work in continuous conduction mode. The switch Sw1 is on, the diode will be reverse biased, the current across the inductance is increased and power is transferred to the load.

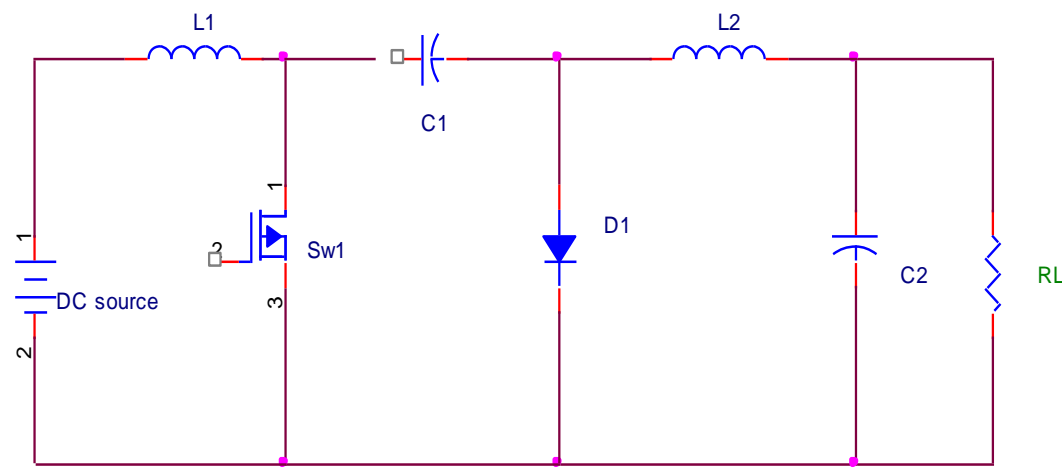

Figure 5. Circuit Diagram of Cuk Converter 
The switch sw1 in the Cuk converter is turned off, the diode function as forward biased and the capacitor is now charging. The output voltage of the Cuk converter is given as

$$
V_{o}=-\frac{V_{\text {in }} D}{1-D}
$$

The Cuk converter has achieved the stable operation and use the inductor and capacitor for reducing the ripple at the output. The converter reduces the switching losses and conduction losses using the MOSFET switches. In Cuk converter the low range of passive elements is used for leading the current regulation. The inductor used as the filter for decreasing the harmonic ripple. In capacitor is used for transferring the energy. The high value of inductance is used and the current flowing through the converter circuit is constant. The high value of capacitance is used to maintain the voltage of converter output.

\subsection{KY Converter}

The KY converter operates in positive current mode. The current flowing through the magnetizing inductor and the output current of the inductor L3 is always positive. The dead time between two switches are neglected. The switch S1 is turned off and Sw2 is turned on. The inductance L3 and L1 are magnetized simultaneously. The C2 is charged and L2 is demagnetized [16]. The voltage across the load is given in equation. Figure 6 shows the circuit diagram of KY converter.

$$
V_{L 2}=V_{c 2}-V_{o}
$$

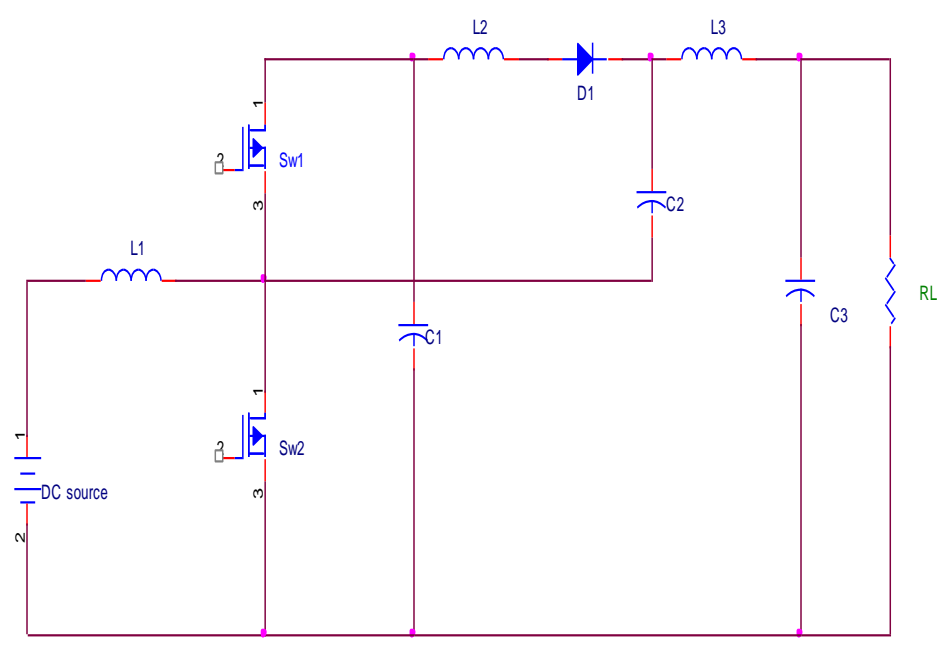

Figure 6. Circuit Diagram of KY Converter

The Sw1 is turned on and Sw2 is turned off. The voltage across L2 is given in equation

$$
V_{L 2}=V_{c 1}+V_{c 2}-V_{o}
$$

\subsection{Multilevel Inverter}

The multilevel inverter is used to reduce the harmonics and increase the performance of renewable energy system. The cascaded $\mathrm{H}$ bridge multilevel inverter is used the single dc source with switched capacitor for attaining high efficiency. The cascaded multilevel inverter generate multilevel with less power supply. This inverter reduces the power switches and function as unidirectional characteristics. The single dc source is used to increase the level and also decrease the total harmonic distortion [18].

The single source can charge the capacitor C1 and C3 by using the charging switch Sw1 and Sw2. The charging circuit contains the power switches and capacitor. The level shifted sinusoidal pulse width modulation has better output voltage compared to the phase shifted sinusoidal pulse width modulation. 


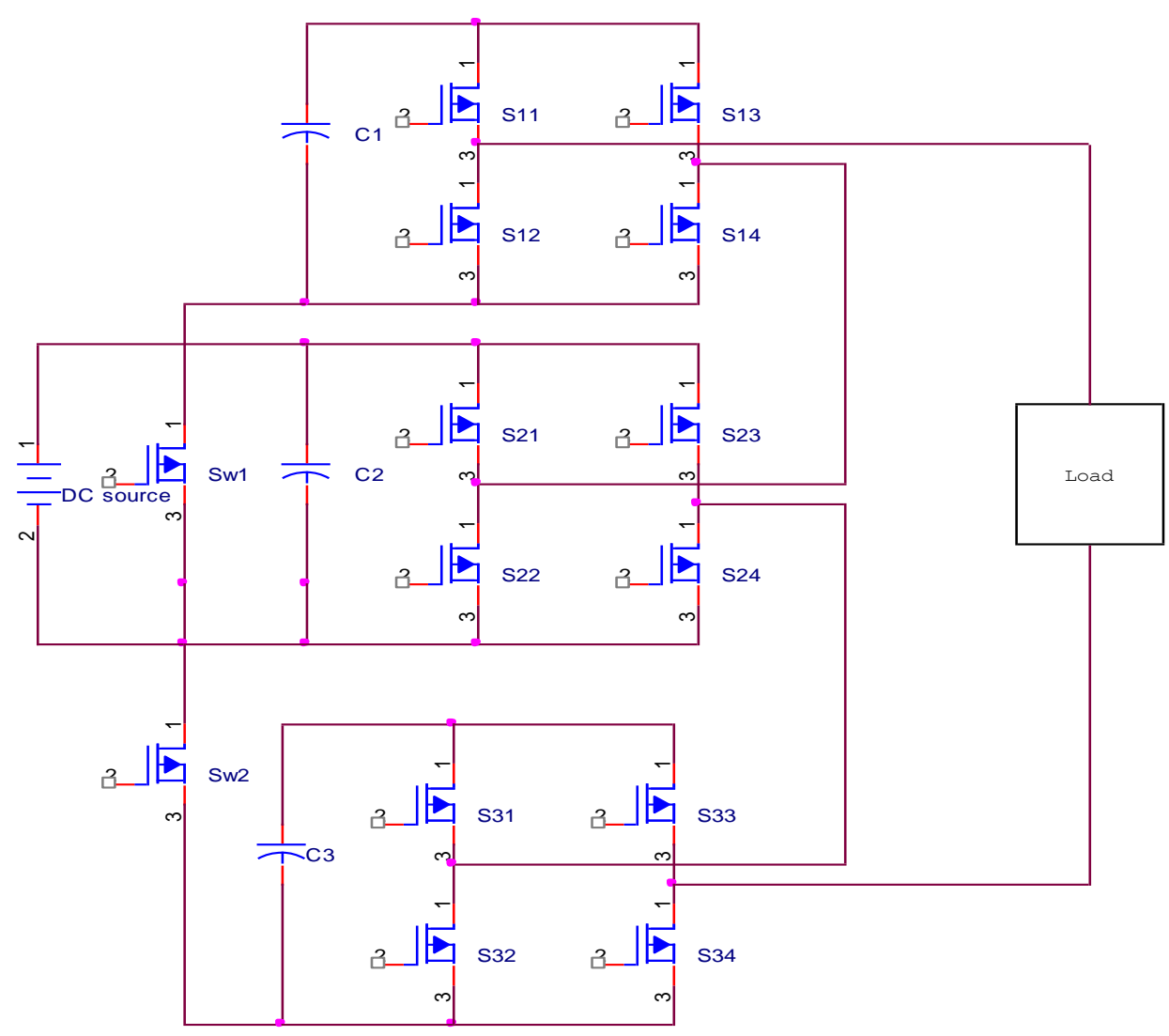

Figure 7. Circuit Diagram of Proposed Multilevel Inverter

\section{PROPOSED CONTROL METHODOLOGY}

The fuel cell based Cuk converter utilizes the PI controller for boost the voltage and photovoltaic based KY converter regulates the voltage by the maximum power point tracking. The carrier phase shifted pulse width modulation is used in the multilevel inverter has three $\mathrm{H}$ bridge inverter share equal power. The switch (S11, S12), (S13, S14), (S21, S22), (S23, S24), (S31, S32), (S33, S34) are operated in complementary manner. The capacitors are charging by switches Sw1, Sw2. The switch Sw1 can be obtained by the switch S13 and S21 by the AND gate and Sw2 is obtained by S23 and S31 can be AND gate circuit. The carrier based phase shifted sinusoidal pulse width modulation is shown in Figure 8.

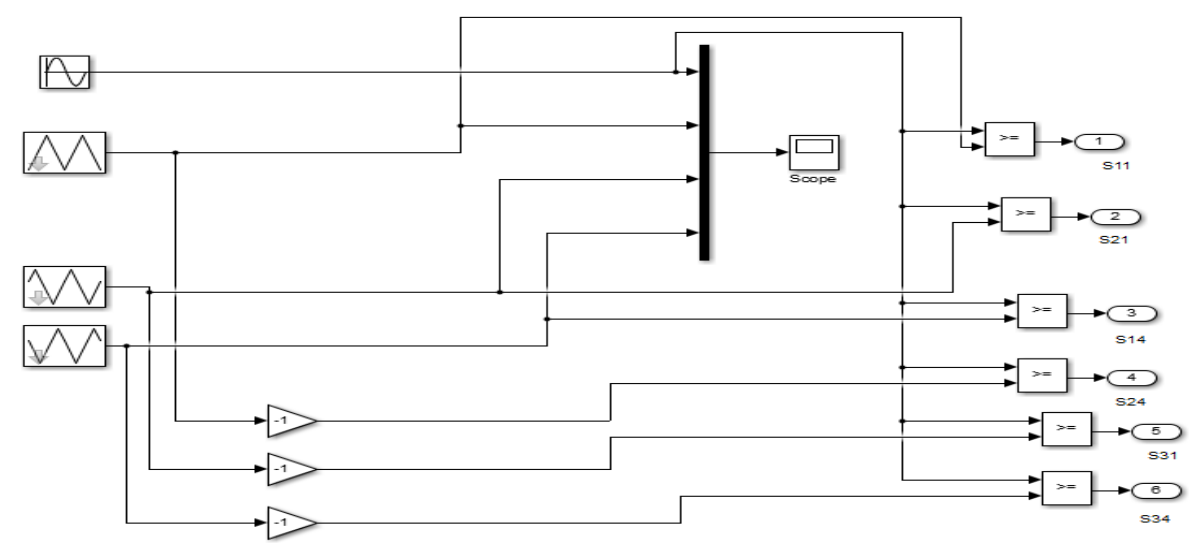

Figure 8. Proposed Carrier Based Phase Shifted Pulse Width Modulation 


\section{RESULTS AND DISCUSSION}

The proposed hybrid renewable energy based multilevel inverter configuration is implemented and results are verified in MATLAB/SIMULINK. The performance of Cuk KY based inverter circuit is analyzed. The improved dual input Cuk -KY converter reduces the conduction losses, lower rating of devices required, the voltage and current stresses are less. Thus, the simulation results also gives the performance analysis such as higher efficiency, required smaller size of energy storage elements and lower rating of switching devices. The Simulink model of proposed hybrid system is shown below in Figure 9. The Simulink parameters are specified is given in Table 1. The PV output voltage waveform is shown in Figure 10. The PV output current waveform is shown in Figure 11. The DC link voltage waveform of Cuk- KY converter is shown in Figure 12. The multilevel inverter output voltage waveform is shown in Figure 13. The total harmonic distortion is shown in Figure 14.

Table. 1 Simulation Parameters Specification

\begin{tabular}{cll}
\hline S.NO & PARAMETERS & VALUE \\
\hline 1 & Solar Voltage & $30 \mathrm{~V}$ \\
2 & Fuel Cell Voltage & $30 \mathrm{~V}$ \\
3 & Switching Frequency & $50 \mathrm{~Hz}$ \\
4 & Battery Capacity & $55 \mathrm{Ah}$ \\
5 & Output Voltage & $65 \mathrm{~V}$ \\
6 & Filter Capacitance & $90 \mathrm{e}-6_{\mathrm{F}}$ \\
\hline
\end{tabular}

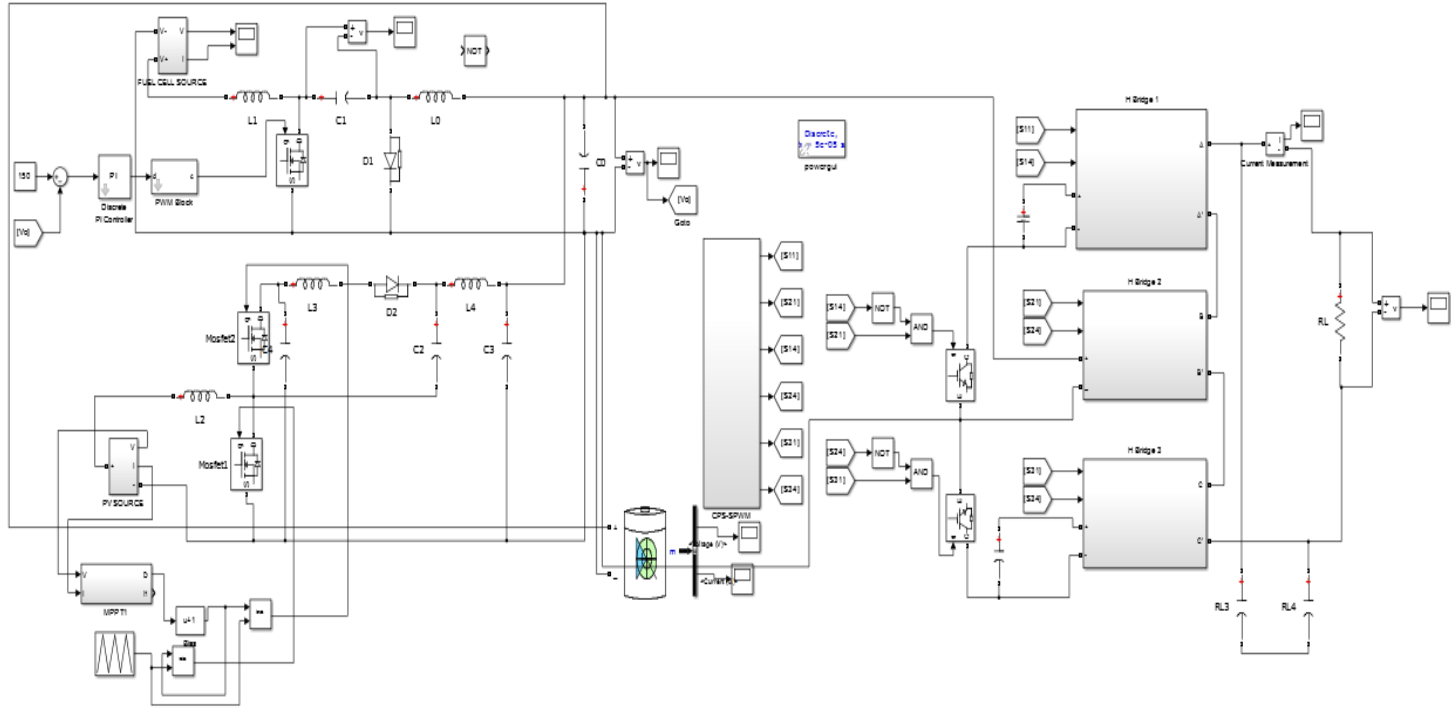

Figure 9. Simulink Model of Overall Proposed Circuit Configuration

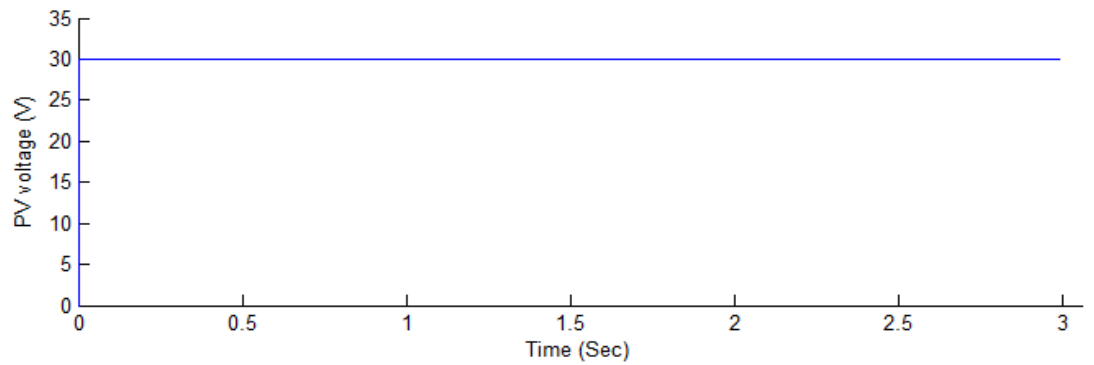

Figure 10. PV Output Voltage Waveform 


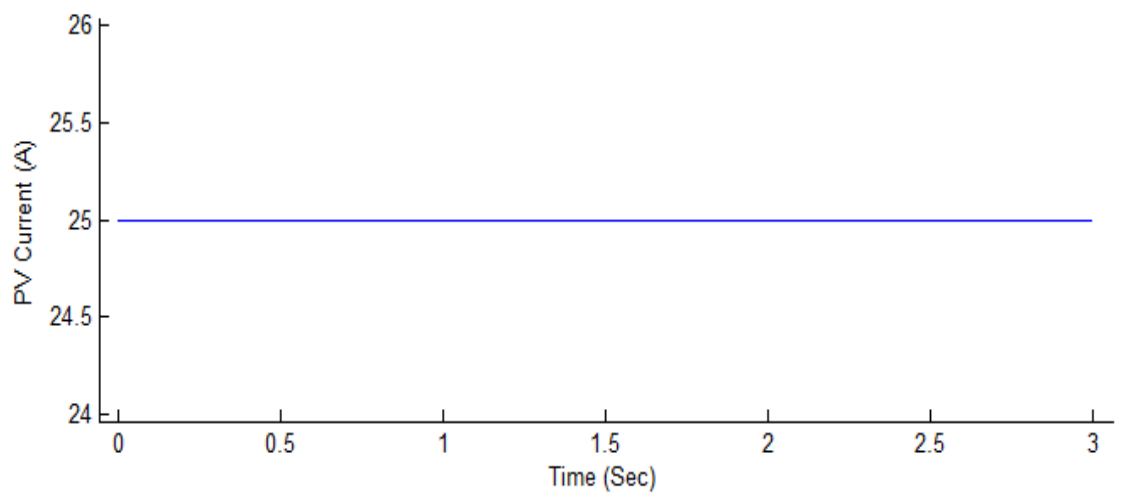

Figure 11. PV Output Current Waveform

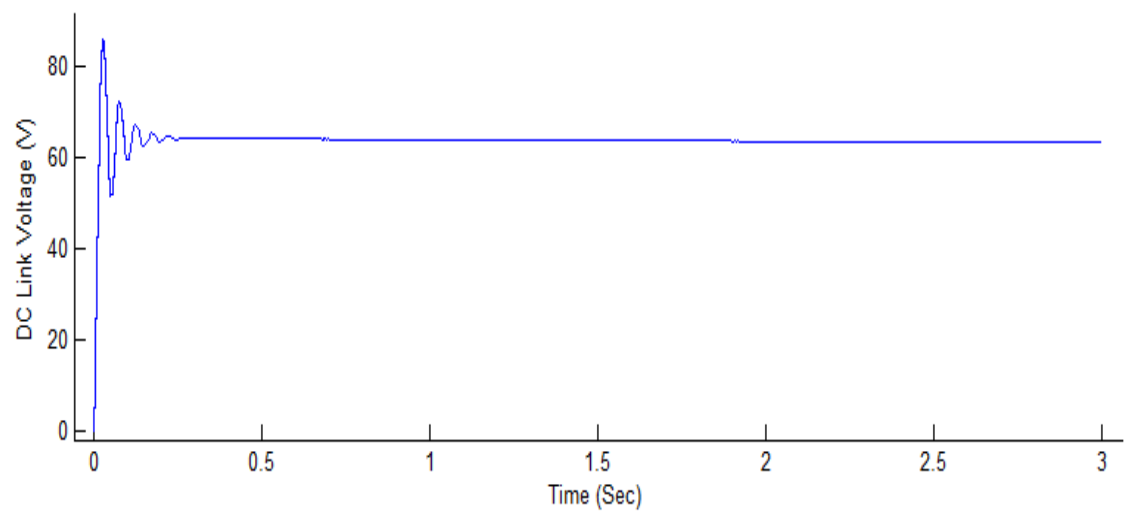

Figure 12. DC Link Voltage Waveform of Cuk-KY Converter

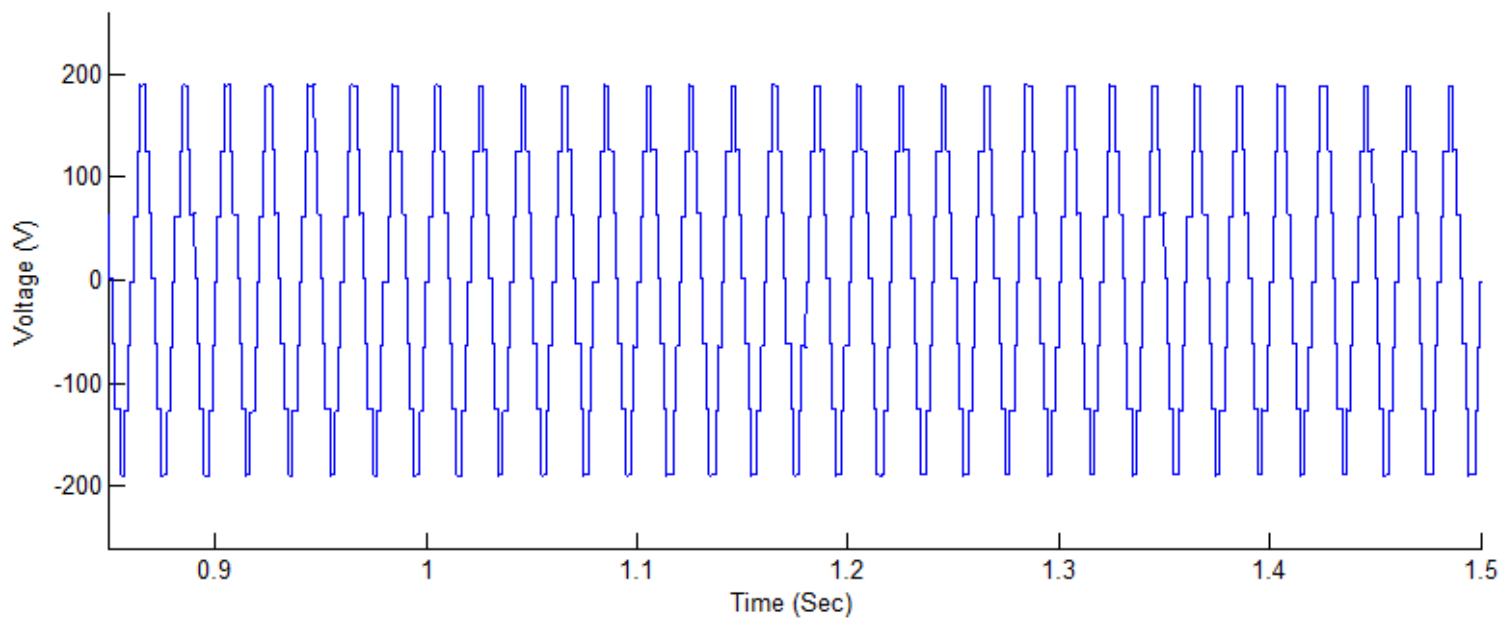

Figure 13. Multilevel Inverter Voltage Waveform 


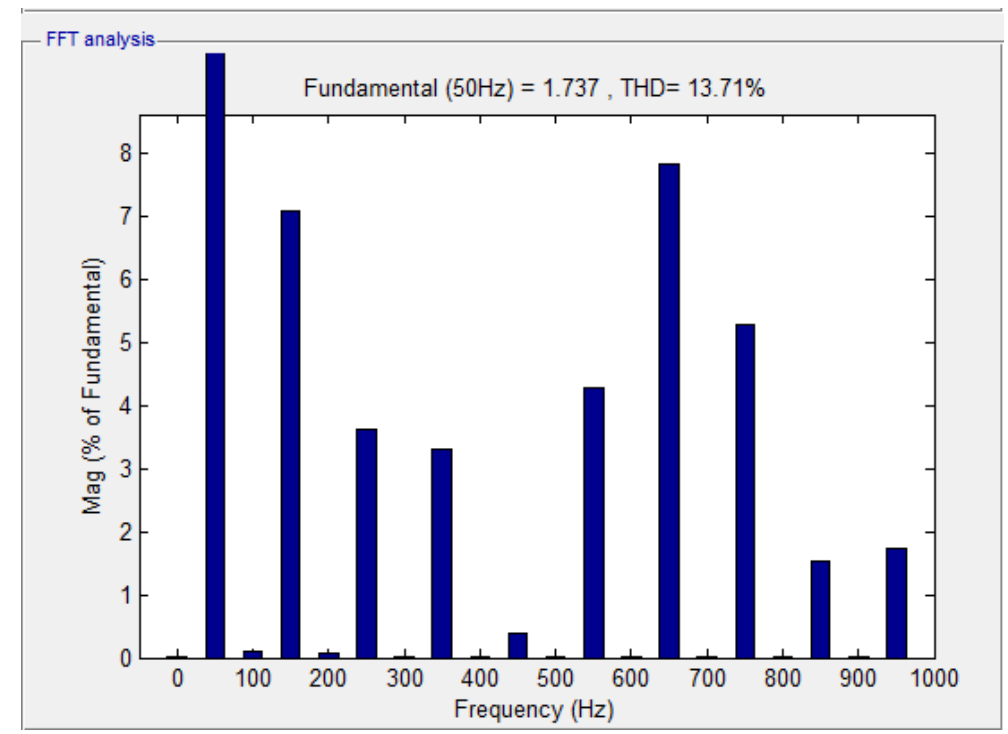

Figure 14. Total Harmonic Distortion of Proposed Hybrid Sources Based Multilevel Inverter

\section{CONCLUSION}

The hybrid renewable energy such as photovoltaic and fuel cell power generation are implemented and analyzed for high gain with less harmonic distortion. The Maximum power point tracking method is designed in the photovoltaic based KY converter is integrated with the fuel cell based on the CUK converter. The PI control method is used in the fuel cell for improving the performance. The multilevel inverter for reduced the harmonics by integrating CUK KY converter. The proposed multilevel inverter fed hybrid converter for increasing the performance of drive system. The maximum power point tracking control method is design for generating the gate pulse for voltage regulation. The photovoltaic and fuel cell are used to attain the high voltage gain by using the MPPT and PI control method. The dc link voltage is regulated by the hybrid renewable energy based on various control method. The performance of distributed energy sources has implemented in MATLAB/SIMULINK environment.

\section{REFERENCES}

[1] Poorali B, et al., "Soft-switching DC-DC Cuk converter operating in discontinuous-capacitor-voltage mode," IET Power Electronics.vol. 10, pp. 1679-1686, 2013.

[2] Joseph K. D, et al., "Interleaved cuk converter with improved transient performance and reduced current ripple," Journal of Engineering-Joe (2017).

[3] Sun, et al., "An improved maximum power point tracking algorithm with CUK converter for PV systems," The Journal of Engineering vol. 1, 2017.

[4] Ananthapadmanabha, et al., "Electric Vehicle Battery Charger with Improved Power Quality Cuk-Derived PFC Converter," Journal of Green Engineering vol. 7, pp. 255-284, 2017.

[5] Li, Dan, et al., "Analysis and Implementation of High-Performance Integrated KY Converter." IEEE Transactions on Power Electronics, 2017.

[6] Hwu, et al., "A KY Converter Integrated with a SR Boost Converter and a Coupled Inductor." JOURNAL OF POWER ELECTRONICS, vol. 17(3), pp. 621-631, 2017.

[7] Aswin P, et al., "A High Efficiency Step-Up DC-DC Converter Combining KY and Multilevel Modular Converter with Low Switching Voltage and Current Stress." Imperial Journal of Interdisciplinary Research, vol. 3(4), 2017.

[8] Gautam, et al., "Reliability improvement of transistor clamped H-bridge-based cascaded multilevel inverter," IET Power Electronics, 2017.

[9] Karasani, et al., "A three-phase hybrid cascaded modular multilevel inverter for renewable energy environment." IEEE Transactions on Power Electronics vol. 32, pp. 1070-1087, 2017.

[10] Gupta, et al., "Multilevel inverter topologies with reduced device count: A review." IEEE Transactions on Power Electronics vol. 31, pp. 135-151, 2013.

[11] Karimi, et al., "A developed single-phase cascaded multilevel inverter with reduced number of circuit devices." International Journal of Ambient Energy, vol. 1, 2017.

[12] Harish, D, et al., "Three Phase Modular Multilevel PV Inverter with Distributed MPPT for Grid-Connected Applications." IJSEAT, vol. 5, pp. 118-124, 2017. 
[13] SAHOO S, et al., "Phase Shifted Carrier Based Synchronized Sinusoidal PWM Techniques for Cascaded H-Bridge Multilevel Inverters," IEEE Transactions on Power Electronics, 2017.

[14] McGrath B, et al., "Optimized Phase Disposition (PD) Modulation of a Modular Multilevel Converter," IEEE Transactions on Industry Applications, 2017.

[15] Tezer, T, et al., "Evaluation of approaches used for optimization of stand-alone hybrid renewable energy systems," Renewable and Sustainable Energy Reviews, vol. 73, pp. 840-853, 2017.

[16] Priya.A, et al., "Performance Development of A BLDC Motor Driven Water Pump Using KY Converter," Indonesian Journal of Electrical Engineering and Computer Science, vol. 9, pp. 602-605, 2018.

[17] Rahnamaei. A, et al., "A Novel Grid Connected Photovoltaic System," Bulletin of Electrical Engineering and Informatics, vol. 5, pp. 133-143, 2017.

[18] Goh, et al., "Predictive Direct Power Control (PDPC) of Grid-connected Dual-active Bridge Multilevel Inverter (DABMI)," International Journal of Power Electronics and Drive Systems (IJPEDS), vol. 8, 2017. 